\title{
The Hijrah Trend Among Indonesian Celebrities in the Perspective of Psychology of Religion
}

\author{
$1^{\text {st }}$ M. Zidni Nafi ${ }^{1}, 2^{\text {nd }}$ Arif Zamhari ${ }^{2}, 3^{\text {rd }}$ Alvin Noor Sahab ${ }^{3}, 4^{\text {th }}$ Murodi $^{4}, 5^{\text {th }}$ Suparto $^{5}$, \\ $6^{\text {th }}$ Rena Latifa ${ }^{6}$ \\ \{m.zidni18@mhs.uinjkt.ac.id ${ }^{1}$, arif.zamhari@uinjkt.ac.id², alvin.noor18@mhs.uinjkt.ac.id ${ }^{3}$, \\ murodi@uinjkt.ac.id ${ }^{4}$, suparto@uinjkt.ac.id ${ }^{5}$, rena.latifa@uinjkt.ac.id ${ }^{6}$ \} \\ Graduate School Syarif Hidayatullah State Islamic University of Jakarta, Indonesia ${ }^{123456}$
}

\begin{abstract}
Recently, the phenomenon of the hijrah movement has emerged in various urban circles, especially Indonesian celebrities, who have been in the spotlight in the media. The trend of hijrah among Indonesian Muslims can be analyzed through several approaches, including one of which is the psychological approach to religion. Through this approach, the question arises, how does the psychology of religion see human relationships and religious behavior? Then what are the motives and orientations of the celebrity's hijrah given the psychological theories of religion? The current trend of hijrah is a phenomenon of the transformation of the meaning of hijrah itself. At first, the hijrah was a history of the movement of the Prophet and his companions from Mecca to Medina due to discrimination and oppression by the Quraish. This history is then interpreted as religious attitudes and behaviors whose principles are self-change to be more positive and better than before. In this article, the psychology of religion serves to describe matters relating to the behavior of religious followers. In this context, the psychology of religion sees the hijrah as a religious expression that tends to fall into the experiential dimension of a person who experiences a spectacular moment that touches his heart due to the presence of an extraordinary figure, namely the one called God. Also, the psychology of religion considers that hijrah is part of the type of religious conversion which is dominant in social and intellectual conversion. In this type, many Indonesian celebrities have changed communities and their understanding of the teachings of Islam. Such religious conversion has an impact on the attitudes and behavior of celebrities after walking on the path of hijrah. In an equally important part, according to the psychological analysis of religion, hijrah has a certain motive and orientation. The celebrities emigrated for several motives, but in theory the orientation of extrinsic, they do it because of the possibility to exist on the world stage entertainment with character and appearance of a more Islamic. That way, they can still compete to fill entertainment or market advertising products. However, in intrinsic theory, the celebrities choose the hijrah way because they want to have a new atmosphere in life, especially the inner calm that has been difficult to obtain while living a life which for them is far from Islamic teachings.
\end{abstract}

Keywords: Hijrah, Celebrity, Psychology of Religion.

\section{Introduction}

Several years back to the present many celebrities began to tread the path of guidance. They chose Hijrah as the path towards the good of Islam, namely of the world to a world of 
sinners' light of faith and piety. ${ }^{1}$ Not only as a religious phenomenon, but hijrah has also become a new trend, starting from the social media universe to forming communities in various regions.

The hijrah trend among Indonesian celebrities in this regard contributed greatly to attracting public attention. In line with this, Haidar Bagir argues that the hijrah is a sign of the Is lamization of public space in Indonesia, even though this religious trend has also occurred in the Western world with the termborn again. ${ }^{2}$ That is public Islamization as an expression of abandoning un-Islamic actions and then becoming more Islamic. Such expressions no longer take place in the private sphere or secret but are shown in public or in general. This trend causes celebrities who have migrated to compete to do da'wah, to invite the public (read: fans ) or other celebrities to follow in their footsteps. ${ }^{3}$

Celebrities who chose to move backgrounds vary. For example, celebrities who are poor across the world of music include Uki Noah, Mulan Jameela, Irwansyah, Ifan Seventeen, Rizal Armada, Reza Noah, Sunu Matta Band, Virgoun Sakti Sheila on 7, and Berry Saint Loco. Also, there is artis cast of soap operas and films, such as Arie Untung, Teuku Wisnu, Shireen Sungkar, Ricky Harun, Roger Danuarta, Donita, and many names of famous others.

Each of the names of celebrities above also has different principles regarding the world of entertainment that they have been struggling with. Some of them leave completely and then take up new professions, such as the culinary business, clothing boutiques, umrah travel. Some of us still became a public figure, but changing the appearance like never before, like wearing the hijab in accordance syar'i, elongate bristle beard, acting as Islamic leaders, not jumped into the role that conflict with religious laws. And what's interesting is that several names of celebrities turned into preachers or lecturers who broadcast Islamic teachings by various methods. Their fame is what is then followed or as an inspiration by some people (read: fans) to join the hijrah movement.

Several approaches can be used to capture the trend of hijrah among these celebrities, for example, ideological, sociological, anthropological, and marketing approaches. However, in the context of this article, the psychology of religion functions as an approach to describe the behavior of a person who chooses the path of hijrah. This approach was chosen because hijrah is a religious expression among Muslims that has emerged in the contemporary era. Also, the psychology of religion as a branch of psychology plays a role in the study of human behavior that air links with religious beliefs against dianu tnya.

Therefore, this article raises two main questions; How does the psychology of religion see human relationships and religious behavior? Then what are the motives and orientations of the artist's hijrah given the psychological theories of religion? This article will answer this question using some of the theories familiar with the psychology of religion.

\section{Meaning of Hijrah}

The current hijrah movement can be said to be a phenomenon of the transformation of the meaning of the hijrah itself. It can be observed that the term hijrah is a word in the Arabic

\footnotetext{
${ }^{1}$ C. Su, Semua Indah Karena Hijrah. Yogy akarta: Deepublish, 2018, pp. 34.

${ }^{2}$ H. Bagir, Islam Tuhan Islam Manusia. Bandung: Mizan, 2019, pp. 57-59.

3 A. Amna, "Hijrah Artis sebagai Komodifikasi Agama". Sosiologi Reflektif, vol. 13, no. 2, pp. 333, Apr. 2019
} 
language which comes from the word هاجر - يهاجر - هجرة which means "move". This movement occurs from one place to another. If it is associated with the hijrah of people I slam, move that is meant is the transfer of Muslims from Mecca towards Madina. In Islam, hijrah, which means displacement, is considered a form of worship with a high reward value. In many verses the Al-Qur'an, Allah explain the worship of glory and promise great rewards to those who emigrate. ${ }^{4}$

Many scholars explain the meaning of hijrah in syar'ior terms. The number of definitions is because the meaning of the word hijrah is not small. Therefore, the opinion of the scholars regarding hijrah is not the same. Some scholars define global hijrah, but there is also a detailed definition of hijrah. Definition syar'i migrated among others namely perp beauty of the land of the infidels or conditions of war (dar al-kufr wa al-harb) to the land of the Muslims (dar al-Islam). ${ }^{5}$

According to them, the land of the infidels referred to above is a country whose government is controlled by infidels on their legal basis. Based on the condition, Mohammed bin Said al-Qathani mention two groups emerged, namely, the land of the infidels who fought the Muslims and the land of the infidels who protected the existence of the Muslims. Meanwhile, the meaning of a Muslimcountry is a country whose government is controlled by Muslims by applying Islamic law even though the majority of the population consists of infidels. ${ }^{6}$

Abu Husain Ahmad, as quoted by Aswandi, divides hijrah into two main points of meaning. First, hijrah means breaking up on one side and continuation on the other. For example, there is a group of residents leaving a village to go to another village. This is like the Muhajirin who left the city of Mecca for the city of Medina. Second, the word hijrah means a broad lake, interpreted this way because the lake is something that stops water. ${ }^{7}$

In terms of terminology, in the book of Fath al-Bari, hijrah can be divided into two types, namely, hijrah physically and hijrah mentally. The mental hijrah term is the abandoning of something that induces anger because of following the devil's footsteps to carry out evil. While the term is born, hijrah is avoiding various slander by maintaining religion. ${ }^{8}$

As for Abdullah Gymnastiar (Aa Gym), the term hijrah means moving from one state to another. In other words, making a move fromone place to another. On the other hand, hijrah also has two meanings. There is hijrah in meaning (ma'nawiyyah) and there is hijrah physically (makaniyyah). The meaning of hijrah in meaning is personality hijrah, namely from previous personal circumstances towards a better state in the aspects of birth and mentally. Then the definition of physical hijrah is moving from one place to another where the situation is better. ${ }^{9}$

Meanwhile, today's hijrah is used to refer to repentance. Ontologically, the terms hijrah and repentance have something in common, namely, they both believe that repentance is the door to return to the divine way. For them - especially celebrities - who have walked the path

\footnotetext{
${ }^{4}$ Abdurrahman, Kitab Sejarah Nabi Muhammad SAW. Yogy akarta: Diva Press, 2013, pp 415416.

${ }^{5}$ Ahzami Samiun Jazuli, Hijrah dalam Pandangan Al-Quran. Depok: Gema Insani, 2006, pp.

17.

${ }^{6}$ Ahzami Samiun Jazuli, pp. 17.

${ }^{7}$ Aswadi, "Refomulasi Epistemologi Hijrah dalam Dakwah". Islamica, vol. 5, no. 2, pp. 341, Mar. 2011.

${ }^{8}$ I. Hajar al-Asqalani, Fath al-Bari. Beirut: Dar al-Ma'rifah, 1959, pp. 54.

${ }^{9}$ A. Gymnastiar, Hijrah: Gerbang Kesuksesan, 3rd ed., Bandung: Emqies, 2012, pp. 9-10.
} 
of repentance by leaving their old world, then intensely participated in studies with several ustadz, then some actively broadcast Islam through their social media. ${ }^{10}$

Thus, the substance of the term hijrah is inseparable from the linguistic meaning. The word hijrah which implies moving or displacement, then in the meaning of the term means changing or moving from a bad state to a better state.

The celebrities chose the path of hijrah not without reason. There are a variety of factors, background, and reasons that drive themselves them to change the attitude or leave the world of entertainment made his name. Even though it seems something 'heavy', it is done because there are certain goals related to the religious views they believe in.

Meanwhile, Quraish Shihab in interpret the verse fragments حتى يهاجروا في سبيل الله (Until they migrate in the way of Allah ) in Surat an-Nis a verse 89 states that the hijrah word in the paragraph is to be understood as an attitude and behavior that shows the stability of faith and seriousness in carrying out the teachings of Is lam. ${ }^{11}$

From a series of explanations about the background above, it is clear that the meaning of hijrah, both etymologically and terminologically, leads to the principle of positive change or for the better. Also, the meaning of 'hijrah' has a close meaning with the word 'taubat', it's just that the use of the term hijrah is more familiar among millennials.

\section{Psychology of Religion}

In the view of psychology, hijrah is a part of behavior that can be observed and analyzed through certain approaches. In this case, the psychology of religion serves to describe matters relating to the behavior of religious followers. In this initial assumption, hijrah is not just a trend, because there are religious dimensions that do experience a kind of turmoil in people who claim to hijrah.

The psychology of religion is not a school or school in psychology, because the schools recognized throughout the world consist of psychoanalysis, behaviorism, and humanism. In this case, the psychology of religion has a position as a branch of psychology. Other branches of psychology, for example, abnormal psychology, educational psychology, communication psychology, industrial psychology, cross -cultural psychology, and others.

Psychology of religion consists of two words, namely "psychology" and "religion". Psychology comes from the Greek "psyche" and "logos". Psyche means soul, while logos means science. So, psychology is the study of the soulboth regarding its various symptoms, processes, and background. Psychology discussion is inseparable from talking about the spirit or body that is contained in humans. ${ }^{12}$

According to Max Weber, defining religion is something that is 'impossible' to do. This is because religious behavior is very diverse. ${ }^{13}$ According to Prof. Dr. Bouquet defines religion is

99.

${ }^{10}$ E. AH Iyubenu, Tuhan Itu 'Maha Santai', Maka Selowlah. Yogyakarta: Diva Press, 2019, pp.

${ }^{11}$ M. Quraish Shihab, Tafsir Al-Mishbah: Pesan, Kesan, dan Keserasian Al-Qur'an, Tangerang Selatan: Lentera Hati, 2005, pp. 546.

${ }^{12}$ Y. Masduki and I. Warsah, Psikologi Agama. Palembang: Tunas Gemilang Press, 2020, pp. 2.

${ }^{13}$ Max Weber, Sosiologi Agama. Yogy akarta: IRCiSoD, 2012, pp. 97. 
a permanent relationship between human beings and non-humans which is holy and supernature, and which is self-existent and has absolute power which is called God. ${ }^{14}$

Judging from the Sanskrit language, the word religion can be interpreted from its structure, namely, $a$ means no, and gama means going, so not going. It means staying in place; inherited from generation to generation. In the term Fachroeddin al-Kahiri, religion is defined by a means no, gama means messy, messy, chaos (Griek). This means it's not messy, it's not messy. Some interpret religion as a text or a holy book. ${ }^{15}$

In terminology, Harun Nasution ${ }^{16}$ provides the following definitions of religion:

a. Recognition of a human relationship with supernatural powers that must be obeyed.

b. Recognition of the existence of supernatural powers that dominate humans.

c. Binding oneself to a form of life that contains recognition at a source that is outside of humans and which affects human actions.

d. A system of behavior (code of conduct) that comes from supernatural powers.

e. Belief in a supernatural power that gives rise to a certain way of life.

f. Recognition of the obligations that are believed to come from a supernatural power.

g. Adoration of supernatural powers that arises from feelings of weakness and fear of mysterious forces that exist in the natural world around humans.

h. The teachings that God revealed to man through an Apostle.

For many people, the term religion must have a different picture. Some consider religion as a way and way of life; religion is the belief in things or realities that are higher than humans; religion is a series of typical actions such as prayer, worship, and ceremony; and others consider religion to be a feeling of being dependent on a reality that transcends itself.

The core and source of religion is religiosity, namely the feeling and awareness of human relations and reconnection with God because humans have known and re-experienced God, and believe in Him. From this awareness of the relationship and bond with God, religion emerges with its four main elements: dogma, doctrine or teaching; worship or cult; morals or ethics; institution, or organization. ${ }^{17}$

Therefore, when religion becomes the object of observation, what can be examined is religion as it is accepted by its adherents through thoughts, feelings, and actions. That is the object of study from the psychology of religion. In this case, hijrah is positioned as an object of observation because it is a religious phenomenon of celebrities. From religious observations through several theoretical approaches, it will be known to what extent the motivation and orientation of the artist's hijrah.

\section{Religious Behavior, Hijrah Motives, and Orientation}

Every human being born in the world carries nature, talents, and instincts. What humans bring at birth is religious nature, namely the divine element. This divine element is beyond the creation of the human mind and is a natural trait of man. The incidence of humans as God's

\footnotetext{
${ }^{14}$ A. Ahmadi, Sejarah Agama. Solo: Ramadhani, 1984, pp. 14.

${ }^{15}$ R Abuy Sodikin, “Konsep Agama dan Islam”, Jurnal Al-Qalam, vol. 20, no. 97, pp. 2, Jun.

${ }^{16}$ H. Nasution, Teologi Islam. Jakarta: UI Press, 1985, pp. 9-11.

17 A. M. Hardjana, Religiositas, Agama dan Spiritualitas. Yogy akarta: Kanisius, 2005, pp. 51.
} 2003 
creatures has been equipped with the elements of humanity, justice, virtue, and so on. Humans and religion seem to be a natural relationship. Religion itself is united like human creation. ${ }^{18}$

Every human being has different abilities in knowing, understanding, and carrying out religious teachings. So that the level of religion in each religious adherent becomes different. It is not surprising that Paloutzian in Invitation to the Psychology of Religion as quoted by Jalaluddin Rakhmat classifies religious followers based on the dimensions of ideological (belief), intellectual (knowledge), consequential (due to religion).

From the above dimensions, it seems to have an impact on the diversity of characteristics of religious adherents. Jalaluddin Rakhmat divides religious followers into four groups bas ed on the relationship between belief and knowledge.

a. Faith of knowledge: There is faith and there is knowledge. For example, he defended his beliefs to the fullest and knew deeply about his religious teachings.

b. Blind faith: There is faith, there is no knowledge. He believes his religion blindly, maybe just following those around him.

c. Rejection of knowledge: There is no faith, there is knowledge. For example, he knew a lot about the teachings of his school. In the process of searching for the truth, he finally refused to believe in the teachings that he previously believed in.

d. Blind refusal. No faith, no knowledge. For example, he rejected one school or one religion because he did not know anything about that school or religion. ${ }^{19}$

Also, Jalaluddin Rakhmat classifies humans based on the relationship of faith and experience, ideological dimensions and consequential dimensions, into four groups:

a. Believers are consistent: There is faith and there is charity. If his faith teaches righteous deeds, he fills his time with righteous deeds.

b. Hypocrisy: There is faith, there is no charity. He confessed that he believed that the Prophet Muhammad SAW, perfected morals, but he had a taste for slandering other people.

c. Moral agnostic: No faith, but good deeds. He does not believe in his religious teachings, but in social life, he shows good behavior (as if the impact of his religious teachings).

d. Consistent Non-believers: There is no faith and no charity. He does not believe in religious teachings and lives his life disregarding religious norms. ${ }^{20}$

Departing from the above division, it can be seen that the knowledge possessed and the experience experienced by a religious adherent is closely related to the quality and character of the emigrating artist. In other words, the attitudes, behavior, and actions of religious people are not only limited to the doctrine or teaching factors given by their religion but personality factors also greatly determine the style and quality of one's hijrah.

Thus, the hijrah of its celebrities at least can be included in a consistent believer class categories, namely totally committed to the principle of hijrah, so it does not seem moral hazard and seasonal obedience in divine path. Can also celebrities who emigrated included in the proselytes who only follow the trend, even by some of the growing phenomenon, some celebrities chose to move because to win the 'market' in the new stage entertainment which

\footnotetext{
${ }^{18}$ Y. Masduki and I. Warsah, Psikologi Agama, pp. 29.

${ }^{19}$ J. Rakhmat, Psikologi Agama: Sebuah Pengantar. Bandung: Mizan, 2004, pp. 44-47.

${ }^{20}$ J. Rakhmat, Psikologi Agama, pp. 48.
} 
began targeting Muslim groups were familiar with the fashion world, food, cosmetic, and so forth. This is where many emerging celebrities competing migrated as endorsement products on the market.

According to Robert H. Thouless in Ahmad Saifuddin, wrote that there are four types of religious conversion. First, intellectual conversion. This type of religious conversion is not interfered with by elements of moral and social conflict. This type of religious conversion occurs because it is influenced by an individual's intellectual process in viewing several religions and beliefs. Second, moral conversion. Moral conversion occurs as a result of moral conflict. This type of religious conversion can be exemplified when people who are initially far from religion and do not care about religious teachings turn into individuals who are very cautious and very diligent in practicing certain religious teachings. Third, social conversion. An example of this social conversion is when a person changes religions due to the influence of interpers onal relationships, for example leaving their old religion because they want to marry someone of a different religion. Fourth, mystical conversion. The number of cases of mystical conversion is less than the previous three types of religious conversions ${ }^{21}$

Then what about hijrah, which part of the religious conversion is included? In this case, hijrah can fall into the intellectual category concerning the artist's level of knowledge about Is lamic religious knowledge, whether it is at a basic or deep level. Compared to other types, this type of social convention seems to be very close to the phenomena in which many celebrities to be hijrah and then change their communities, for example joining religious study communities.

In connection with the dimensions of religion and the typology of religious adherents, in particular, there are several theories about the relationship between humans and religion from a psychological perspective. As quoted by Jalaluddin, there are two (2) theories that explain the spiritual sources of religion.

First, Monistic Theory, which is the source of religious psychology is a source of psychology. Furthermore, the single source in question is the most dominant as a source of psychology. According to Thomas van Aquino, the psychological source of religion is thinking. Humans are godly because humans use their thinking abilities. Meanwhile, for Fredrick Schleimacher, what is the source of religion is a sense of absolute dependence (sense of depending). With this absolute sense of dependence, humans feel weak. This weakness causes humans to always depend on their lives with a power that is outside of themselves.

Second, the Fakulti Theory, that human behavior is not based on a single source but consists of several elements, among other things that are considered to play an important role are the functions: 1) reason (cipta), namely the intellectual function of the human soul. The science of kalam (theology) is a reflection of the influence of this intellectual function. Through creativity, people can judge, compare, and decide on action against certain stimulants. This intellectual feeling in religion is a reality that can be seen, especially in modern religion, the role and function of this reason are very decisive; 2) emotion (rasa), which is a power in the human soul that a greater role in shaping the motivation in the pattern of behavior. No matter how important the function of reason is, if it is used excessively it will cause religious teachings to cool down.

${ }^{21}$ A. Saifuddin, Psikologi Agama: Implementasi Psikologi untuk Memahami Perilaku Agama. Jakarta: Kencana, 2019, pp. 198. Read more R. H. Thouless, An Introduction to the Psychology of Religion, 3rd Ed., London: Cambridge University Press, 1972, pp. 104-110. 
For this reason, the function of reason is only appropriate to play a role in thinking about the supernatural, while to give meaning in religious life requires a thorough and deep appreciation so that the teaching appears alive. So, what becomes the object of investigation now is not the assumption that one's religious experience is influenced by emotions, but how far the role of emotions plays in religion.

Then the next function, 3) will (karsa), namely the executive function in the human soul. Will functions to encourage the emergence of the implementation of doctrine and teachings based on psychological functions. A belief that is held will not be meaningful at all if that belief will not function normally. ${ }^{22}$

Thus, the monistic theory sees the sense of dependence of celebrities who move to Allah as the Essence of all life. Some may experience situations that are weak, depressed, stressed, or depressed, requiring calm through the hijrah path. Likewise with the faculty theory which analyzes how the religious knowledge of the celebrities affects whether or not they need to declare themselves to hijrah. On another aspect, a sense of motivation is also very close to self-courage in the eyes of the public to be hijrah.

In connection with the emergence of religion in humans, according to Glock (1962) as quoted by Taufik Pasiak, every religion has five dimensions that are interrelated by explaining what happens in the religious process; 1) ideological dimension, namely dimension keimanaan a person, the way he sees the reality based on dogma or faith believed; 2) intellectual dimension, is religious knowledge includes knowledge of the scriptures or other sources of information, the symbols of the story, which is usually integrated into a theology ; 3) ritualistic dimension, namely attendance at places of worship, prayer, participation in religious ceremonies, chanting or religious music can be a source of comfort to certain people; 4) essential dimension. This dimension relates to religious experiences experienced and influencing life, can be either ordinary or spectacular experiences in which a person experiences or feels the presence of a certain figure whom he believes to be God; 5) consequential dimension, namely the influence of religiosity on nonreligious activities. $^{23}$

In this case, hijrah is part of the dimensions of one's religious psychography. When referring to this theory, hijrah is an example of an experimental dimension related to the artist's experience of feelings. There are certain moments where their minds are touched so that there is a desire to change themselves to a better path than before. Also, the celebrities' hijrah can deal with a consequential dimension in which these steps then have an impact on behavior to change their appearance and activities, for example about costumes, the roles they take at shooting, to the religious study communities they follow.

Apart from that, hijrah is a small example of the ideological dimension in classical Islam which was transformed with the current of modernization, so that it seemed like a kind of de javu. That is, hijrah as fundamental teaching in Islam now appears to be a contemporary term. This can be seen from the various literature of Islamic studies that mention the term hijrah a little unless it refers to the hijrah of the Prophet Muhammad from Mecca to Hijaz (Medina).

John Lofland and Norman Skonovd identified six motives in religious conversion: intellectual, mystical, experimental, affective, revivalist, and coercive.

a. Intellectual motive. In this conversion, one seeks knowledge about religious or spiritual issues through books, television, articles, lectures, and other media that do

\footnotetext{
22 Jalaluddin, Psikologi Agama. Jakarta: Raja Grafindo Persada, 2009, pp. 53-58.

${ }^{23}$ T. Pasiak, Tuhan dalam Otak Manusia. Bandung: Mizan, 2012, pp. 187-192.
} 
not involve significant social contact. The person is actively looking for and exploring alternatives. Belief generally occurs before active participation in religious rituals and organizations.

b. The mystical motive is considered by some to be a prototypical conversion. These motives are generally sudden and traumatic outbursts of insight, caused by sight, sound, or other paranormal experiences.

c. Experimental motive. Within this motif has emerged as the main avenue of conversion in the 20th century due to greater religious freedom and the abundance of religious experiences available. Experimental conversion involves active exploration of religious choice. Potential converts (converts) have a "show me" mentality. Many groups promote this mode by welcoming a semi-scientific attitude. Potential converts are urged to take nothing from the faith except to try out theology, ritual, and organization for themselves and discover whether the system is right, that is, it is beneficial or supportive) for them.

d. Affection motive. First identified by John Lofland and Rodney Stark in their essay "Becoming a World-Saver". This motif emphasizes interpersonal ties as an important factor in the conversion process. At the heart of it is the direct and personal experience of being loved, nurtured, and affirmed by the group and its leaders.

e. Revivalism motive. Although less prominent in the 20th century than it was in the 19th century, this type of conversion uses crowd-matching to encourage the behavior. The individual is emotionally aroused and new behaviors and beliefs are promoted by the pressure exerted. For example, revival meetings feature emotionally powerful music and sermons. In addition to the experience of the group, individuals are sometimes sought by family members and friends to give a direct effect on the prospective people who want a cure.

Coercive motives. This type of conversion is relatively rare. Brainwashing, coercive persuasion, thought reform, and programming is other labels for this type of conversion process. Conversion is more or less coercive according to the degree of intense pressure exerted on the person to participate, conform, and confess. Lack of food and sleep can make the person unable to withstand the pressure to give in to the group ideology and compliant lifestyle. Fear, physical abuse, and other forms of psychological terror are employed to gain control over a person's life. ${ }^{24}$

Religion and one's religious behavior are closely related to an orientation towards religion itself. Krauss and Hood define that religious orientation is the way a person becomes religious. In other words, religious orientation is a form of one's faith. This definition of religious orientation implies that people who are not religious have no religious orientation because they do not have a religion. The second definition, religious orientation is the way individuals approach (or avoid) religion. In many ways, this definition is identical to the first. However, unlike the former, this definition implies that non-religious people also have a religious orientation, as everyone approaches (or avoids) religion in some way. ${ }^{25}$

${ }^{24}$ L. R. Rambo, Understanding Religious Conversion. London: Yale University Press, 1993, pp. 14-16.

${ }^{25}$ S. W. Krauss and R. W. Hood Jr., A New Approach to Religious Orientation: The

Commitment-Reflectivity Circumplex, Amsterdam: Brill, 2013, pp.23-24. 
According to Allport and Ross, there are two kinds of religious orientations. First, extrinsic orientation. Religious people of this orientation tend to use religion for their purposes. This term is borrowed from axiology, to denote an interest that is owned because it serves other, more important interests. Extrinsic value is always instrumental and utilitarian. That is, people with this orientation can find religion useful in a variety of ways for providing security and comfort, socializing and distraction, status, and self-righteousness.

Second, intrinsic orientation. People with this orientation find their main motive in religion. Other needs, as strong as possible, are seen as less important. Apart from that, as far as possible his needs are aligned with religious beliefs and propositions. After expressing faith, a person will try to internalize it and follow it completely. It is in this sense that he is called living his religion. ${ }^{26}$

In this context, the orientation of the person who undertakes or chooses to move is certainly related to the goals and interests of the chosen path. Based on Allport and Ross's theory, there are at least two (2) important points for analyzing the artist's hijrah orientation. That extrinsically, the orientation of the artist's hijrah has an interest in increasing his popularity through appearances that are categorized as 'Islamic'. This analysis can be lifted from the phenomenon of female celebrities who hijrah by changing their appearance, for example by wearing a hijab, wide clothes, and things that smell of Muslim identity. Famous names of female hijab celebrities include Kartika Putri, Wulan Jameela, Donita, Nikita Mirzani, Alyssa Soebandono, Chacha Fredica, Zaskia Sungkar. With this new appearance, they were flooded with endorsements of products such as hijab, mukena, cosmetics, Muslim clothing, food, and so on.

In this extrinsic orientation, the hijrah path is not a difficult path for celebrities who wish to migrate. This is because there are many opportunities to look for rupiah coffers in the world of entertainment even though he is identical to Islam because he is part of the hijrah community. This also cannot be separated from the emergence of the phenomenon of religious people who are starting to enjoy showing religious symbols in public spaces and social media in particular.

Although not a few who assess trends in hijrah as a new commodity in the world of entertainment, on the other hand, hijrah motive among others in the cause right there it a spiritual experience be some an artist. This experience is a moment that can touch or shake someone's mind when faced with God's power. So that the hijrah becomes a way for them to improve the quality of religious attitudes that they consider inappropriate for religious people. This intrinsic orientation is an important basis for someone who wants a calm life and lives it amid various life choices that have complex problems. Therefore, these extrinsic and intrinsic orientations go hand in hand with the artist. This is fairly common and fine. Moreover, the psychology of religion places these two orientations as if they were two sides of a coin. Thus, hijrah is an example of how religious orientation has interesting sides for adherents. Even though it looks different, this is a natural phenomenon among religious communities.

${ }^{26}$ G. W. Allport and J. Michael Ross, "Personal Religious Orientation and Prejudice". Journal of Personality and Social Psychology, vol. 5, no. 4, pp. 434, 1967. 


\section{References}

A. Ahmadi, Sejarah Agama. Solo: Ramadhani, 1984.

A. Amna, "Hijrah Artis sebagai Komodifikasi Agama". Sosiologi Reflektif, vol. 13, no. 2, pp. 333, Apr. 2019.

A. Gymnastiar, Hijrah: Gerbang Kesuksesan, 3rd ed., Bandung: Emqies, 2012.

A. M. Hardjana, Religiositas, Agama dan Spiritualitas. Yogyakarta: Kanisius, 2005.

A. Saifuddin, Psikologi Agama: Implementasi Psikologi untuk Memahami Perilaku Agama. Jakarta: Kencana, 2019.

Abdurrahman, Kitab Sejarah Nabi Muhammad SAW. Yogyakarta: Diva Press, 2013.

Ahzami Samiun Jazuli, Hijrah dalam Pandangan Al-Quran. Depok: Gema Insani, 2006.

Aswadi, "Refomulasi Epistemologi Hijrah dalam Dakwah". Islamica, vol. 5, no. 2, pp. 341, Mar. 2011.

C. Su, Semua Indah Karena Hijrah. Yogyakarta: Deepublish, 2018.

E. AH Iyubenu, Tuhan Itu 'Maha Santai', Maka Selowlah. Yogyakarta: Diva Press, 2019.

G. W. Allport and J. Michael Ross, "Personal Religious Orientation and Prejudice". Journal of Personality and Social Psychology, vol. 5, no. 4, pp. 434, 1967.

H. Bagir, Islam Tuhan Islam Manusia. Bandung: Mizan, 2019.

H. Nasution, Teologi Islam. Jakarta: UI Press, 1985.

I. Hajar al-Asqalani, Fath al-Bari. Beirut: Dar al-Ma'rifah, 1959.

J. Rakhmat, Psikologi Agama: Sebuah Pengantar. Bandung: Mizan, 2004.

Jalaluddin, Psikologi Agama. Jakarta: Raja Grafindo Persada, 2009.

L. R. Rambo, Understanding Religious Conversion. London: Yale University Press, 1993.

M. Quraish Shihab, Tafsir Al-Mishbah: Pesan, Kesan, dan Keserasian Al-Qur'an, Tangerang Selatan: Lentera Hati, 2005.

M. Weber, Sosiologi Agama. Yogyakarta: IRCiSoD, 2012.

R Abuy Sodikin, "Konsep Agama dan Islam”. Jurnal Al-Qalam, vol. 20, no. 97, pp. 2, Jun. 2003

R. H. Thouless, An Introduction to the Psychology of Religion, 3rd Ed., London: Cambridge University Press, 1972.

S. W. Krauss and R. W. Hood Jr., A New Approach to Religious Orientation: The Commitment-Reflectivity Circumplex, Amsterdam: Brill, 2013.

T. Pasiak, Tuhan dalam Otak Manusia. Bandung: Mizan, 2012.

Y. Masduki and I. Warsah, Psikologi Agama. Palembang: Tunas Gemilang Press, 2020. 